\title{
Aluminide Thermal Barrier Coating for High Temperature Performance of MAR 247 Nickel Based Superalloy
}

\author{
Mateusz Kopec ${ }^{1,2, *(\mathbb{D})}$, Dominik Kukla ${ }^{1}$, Xin Yuan ${ }^{2}$, Wojciech Rejmer ${ }^{3}$, Zbigniew L. Kowalewski ${ }^{1}$ \\ and Cezary Senderowski ${ }^{3}$ (i) \\ 1 Institute of Fundamental Technological Research, Polish Academy of Sciences, Pawińskiego 5B, \\ 02-106 Warszawa, Poland; dkukla@ippt.pan.pl (D.K.); zkowalew@ippt.pan.pl (Z.L.K.) \\ 2 Department of Mechanical Engineering, Imperial College London, London SW7 2AZ, UK; \\ xin.yuan15@imperial.ac.uk \\ 3 Department of Materials Technology and Machinery, University of Warmia and Mazury, \\ Oczapowskiego 11 St., 10-719 Olsztyn, Poland; wojciech.rejmer@uwm.edu.pl (W.R.); \\ cezary.senderowski@uwm.edu.pl (C.S.) \\ * Correspondence: mkopec@ippt.pan.pl
}

check for

updates

Citation: Kopec, M.; Kukla, D.; Yuan,

X.; Rejmer, W.; Kowalewski, Z.L.;

Senderowski, C. Aluminide Thermal

Barrier Coating for High Temperature Performance of MAR 247 Nickel Based Superalloy. Coatings 2021, 11,

48. https://doi.org/10.3390/ coatings 11010048

Received: 19 November 2020 Accepted: 30 December 2020 Published: 5 January 2021

Publisher's Note: MDPI stays neutral with regard to jurisdictional clai$\mathrm{ms}$ in published maps and institutional affiliations.

Copyright: (C) 2021 by the authors. Licensee MDPI, Basel, Switzerland. This article is an open access article distributed under the terms and conditions of the Creative Commons Attribution (CC BY) license (https:// creativecommons.org/licenses/by/ $4.0 /)$.
Abstract: In this paper, mechanical properties of the as-received and aluminide layer coated MAR 247 nickel based superalloy were examined through creep and fatigue tests. The aluminide layer of $20 \mu \mathrm{m}$ was obtained through the chemical vapor deposition (CVD) process in the hydrogen protective atmosphere for $8 \mathrm{~h}$ at the temperature of $1040{ }^{\circ} \mathrm{C}$ and internal pressure of $150 \mathrm{mbar}$. A microstructure of the layer was characterized using the scanning electron microscopy (SEM) and X-ray Energy Dispersive Spectroscopy (EDS). It was found that aluminide coating improve the high temperature fatigue performance of MAR247 nickel based superalloy at $900{ }^{\circ} \mathrm{C}$ significantly. The coated MAR 247 nickel based superalloy was characterized by the stress amplitude response ranging from $350 \mathrm{MPa}$ to $520 \mathrm{MPa}$, which is twice as large as that for the uncoated alloy.

Keywords: chemical vapor deposition; nickel alloys; aluminide coatings; high temperature fatigue; creep

\section{Introduction}

Nickel alloys are characterized by their superior, high temperature performance properties including corrosion, heat and creep resistance. Hence, they are commonly used in aircraft engines [1,2]. Higher engine combustion temperatures tend to improve the efficiency of the propulsion systems, however, extremely high engine temperature requires an advanced materials that could withstand the operational loads in such aggressive environment [3-5]. The most conventional superalloys for gas turbines are MAR 247 [6], Rene 80 [7] and IN738 [8]. MAR 247 nickel based superalloy exhibit higher strength properties in comparison to these alloys, especially at high temperature. Its yield strength at $1000{ }^{\circ} \mathrm{C}$ is approximately $100 \mathrm{MPa}$ greater that for IN738 and almost two times greater than for Rene 80 [6-8]. Additionally, MAR 247 nickel based superalloy was characterized by improved creep response in comparison to the mentioned alloys. The development of casting technologies led to the fabrication of new generation, cost effective alloys doped with Re and Ru to further increase the temperature stability [9]. However, these elements are expensive and their supply is strategically dangerous [9].

Among the promising solutions that could enhance the high temperature performance of engine elements, one can indicate the application of $\mathrm{Ni}$-Al type intermetallics as coatings material. In such materials, due to their crystalline structure with strong chemical bonds and tightly packed atoms in the lattice, a relatively low diffusion of atoms during recrystallisation occurs. Thus, they are more resistant to creep and high-temperature corrosion in comparison to the classical superalloys. Among the NiAl-type intermetallics, only two phases ( $\mathrm{NiAl}$ and $\mathrm{Ni}_{3} \mathrm{Al}$ ) would allow to form the coating structure, that could transfer high mechanical loads in aggressive corrosive and erosive environments, also at high temperature [10,11]. $\mathrm{Ni}_{3} \mathrm{Al}$ phase 
based intermetallics, exhibit improved fatigue strength at high temperature in comparison to the commonly used Ni-based superalloys [12]. On the other hand, the ordered NiAl phase is characterized by a higher melting point $\left(1640{ }^{\circ} \mathrm{C}\right)$, lower density $\left(5.86 \mathrm{~g} / \mathrm{cm}^{3}\right)$, higher oxidation resistance and higher thermal conductivity $\left(\lambda=76 \mathrm{~W} \mathrm{~m}^{-1} \mathrm{~K}^{-1}\right)$ in comparison to $\mathrm{Ni}_{3} \mathrm{AL}\left(7.5 \mathrm{~g} / \mathrm{cm}^{3}, \lambda=21.4 \mathrm{~W} \mathrm{~m}^{-1} \mathrm{~K}^{-1}\right)[13,14]$. Hence, the superior properties of $\mathrm{NiAl}$ and $\mathrm{Ni}_{3} \mathrm{Al}$ aluminides at high temperature could be potentially utilize as protective coatings for aircraft engine turbines. Generally, thermal barrier coatings are applied to parts of gas turbine to reduce their operational temperature by approximately $100-300{ }^{\circ} \mathrm{C}$ and simultaneously increase their service life [15]. The coatings protect external surfaces of the material when it is in contact with hot gas atmosphere. The additional content of aluminium and chromium in coating allows to form a thermodynamically stable oxide layer that acts as diffusion barrier [16]. Such barrier protects the substrate material and significantly reduce its chemical reactivity during performance in aggressive environment [17-19]. The effect of protective coatings on high temperature performance of nickel based alloys was widely studied in literature. Duplex chromium/aluminium coatings were used to improve the creep performance over 30 years ago $[20,21]$. It was found that the aluminide coatings deposited on nickel superalloys could enhance their mechanical properties at elevated temperature [22,23] through significant reduction of oxidation and carbonisation during high temperature performance [24-27]. Functional properties of aluminide layer deposited on the nickel based superalloys in CVD process have been studied by Yaworska et al. [28]. It should be mentioned that, aluminide thermal barrier coatings for nickel superalloys were found useful in maintaining their superior mechanical properties, especially at high temperature. It has been also found that aluminium-based materials for aluminide coatings enhance the oxidation resistance $[29,30]$ and high temperature performance of nickel superalloys without deterioration of its mechanical properties [31-33]. Since high temperature oxidation contributes to the reduction of the fatigue life at elevated temperatures [19], the application of thermal barrier coatings was found to be extremely important in terms of materials fatigue life. The general comparison of some basic mechanical properties of coatings and nickel based materials for turbine blades at high temperature were recently presented in comprehensive review by Wee et al. [9]. However, the high temperature mechanical response of coated MAR 247 nickel based superalloy were not studied as yet.

Therefore, the main aim of this work was to assess the high temperature mechanical response of conventional MAR 247 nickel based superalloy protected by aluminide coating (TBC) deposited by optimized chemical vapor deposition (CVD) process [34] through creep and fatigue tests. Such tests enabled both, characterization of the mechanical properties of material in question and assessment of an actual effectiveness of the CVD process parameters optimized in authors previous paper [34].

\section{Materials and Methods}

MAR 247 nickel based superalloy specimens were manufactured using casting process and uniform crystallization performed in ceramic moulds. Specimen casting was carried out in an ALD vacuum furnace. Specimens made of MAR 247 nickel based superalloy with directional grain orientation (DS) were transferred outside of the furnace under controlled speed of $3 \mathrm{~mm} / \mathrm{min}$. Specimens with equiaxed microstructure (EQ) were quenched in the furnace to achieve the required microstructure. The chemical composition of MAR247 nickel based superalloy was presented in Table 1 .

Table 1. Chemical composition of MAR 247 nickel based superalloy (wt.\%).

\begin{tabular}{cccccccc}
\hline $\mathbf{C}$ & $\mathbf{C r}$ & $\mathbf{M n}$ & $\mathbf{S i}$ & $\mathbf{W}$ & $\mathbf{C o}$ & $\mathbf{A l}$ & $\mathbf{N i}$ \\
\hline 0.09 & 8.80 & 0.10 & 0.25 & 9.70 & 9.50 & 5.70 & bal. \\
\hline
\end{tabular}

Aluminide coatings were produced by chemical vapour deposition (CVD) using Ion-Bond setup (Ion Bond Bernex BPX Pro 325 S, IHI Ion bond AG, Olten, Switzerland) located in the Materials Testing Laboratory for the Aviation Industry of the Rzeszów 
University of Technology, Rzeszów, Poland. It was a low activity aluminium process. The optimised CVD processes were executed in the hydrogen protective atmosphere for $8 \mathrm{~h}$ at the temperature of $1040^{\circ} \mathrm{C}$ and internal pressure of $150 \mathrm{mbar}$ [34]. The microstructural characterization and chemical composition analysis of the coatings were examined using Hitachi 2600N scanning electron microscope with Energy Dispersive Spectroscopy (EDS) attachment (Oxford Instruments, Oxford, UK) and HITACHI 260 (Hitachi, Tokyo, Japan) also with an EDS detector. The microhardness of the as-received and coated material was determined on a ZWICK hardness tester (Materialprüfung 3212002, Ulm, Germany) using the Vickers method. Standard and high temperature fatigue tests were performed on the MTS 810 testing machine (MTS System, Eden Prairie, MN, USA) equipped with the conventional and high temperature MTS extensometers. Uniaxial tensile tests were performed at strain rate equal to $2 \times 10^{-4} \mathrm{~s}^{-1}$. Fatigue tests at room and high temperatures were force controlled under zero mean value and constant stress amplitude with a frequency of $20 \mathrm{~Hz}$. The range of stress amplitude from $350 \mathrm{MPa}$ to $650 \mathrm{MPa}$ was established on the basis of the yield point $\mathrm{R}_{0.2}$ determined from the uniaxial tensile test. High temperature fatigue tests were carried out at $900{ }^{\circ} \mathrm{C}$. The geometry of specimens is presented in Figure 1a. Creep tests at $600{ }^{\circ} \mathrm{C}$ under constant stress levels within the range from $700 \mathrm{MPa}$ to $780 \mathrm{MPa}$ were conducted on the standard creep testing machines. The strain measured by two independent sensors were recorded in time internals of $5 \mathrm{~min}$, by two independent sensors. Engineering drawing of the creep test specimens is shown in Figure 1b. The Young's modulus was determined by means of the non-destructive tests in Department of Materials Technology, University of Warmia and Mazury using RFDA (Resonance Frequency and Damping Analyzer, Integrated Material Control Engineering NV, Genk, Belgium) according rules elaborated in the Gordon Laboratory, University of Cambridge [35] and the ASTME 1876-99 standard [36] and this method, an automatic impulser was applied to excite flexural vibrations in the specimen by striking lightly at the center of the specimen. Subsequently, a contactless microphone placed near the end of the specimen was used to register the specimen's mechanical response. Determination of the resonant frequency of natural vibrations damped by internal friction enabled evaluation of the Young's modulus under plane strain state conditions in the elastic range using empirical equations from the Euler-Bernoulli theory [34]. The Young's modulus measurements were carried out at the temperature range from $26^{\circ} \mathrm{C}$ to $900{ }^{\circ} \mathrm{C}$, during annealing and cooling of the specimen at the rate of $3{ }^{\circ} \mathrm{C} / \mathrm{min}$ with subsequent annealing at target temperature for $30 \mathrm{~min}$.

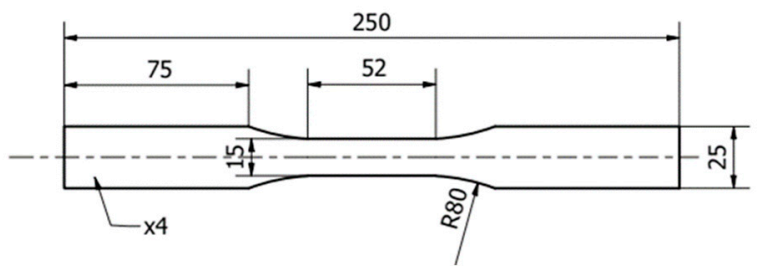

(a)

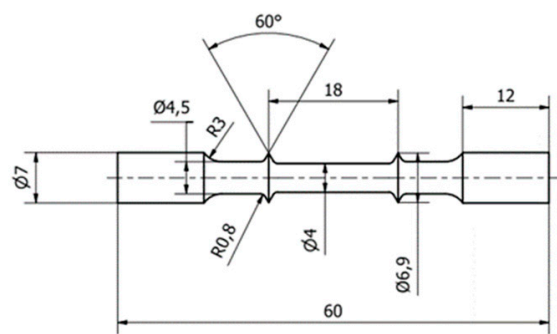

(b)

Figure 1. Geometry of the specimen used for: (a) uniaxial, standard and high temperature fatigue tests; (b) creep tests. 


\section{Results and Discussion \\ 3.1. Microstructural Characterization of Coating during CVD Process}

The structure of the NiAl coating was determined by the growth kinetics of the formed layers and conditioned by the temperature, pressure and synthesis time in the process of chemical vapor deposition. The general view of coating obtained was presented in Figure 2a. It was characterized by uniform thickness of $20( \pm 5 \mu \mathrm{m})$ and was evenly distributed on the MAR 247 nickel based superalloy surface. The intermetallic coating exhibits two-layer structure with approx.11 $\mu \mathrm{m}$ thick homogeneous zone of secondary solid solution of the $\beta(\mathrm{NiAl})$ phase and approx. $12 \mu \mathrm{m}$ heterogeneous $\mathrm{NiAl}$ matrix with $\mathrm{Ni}_{3} \mathrm{Al}$ phase dispersions found within its structure. The interlayer zone was characterized by the lower content of aluminium and the participation of $\mathrm{Co}, \mathrm{Cr}$ and $\mathrm{Ti}$ alloying elements diffusing from the core of raw material (MAR 247 nickel based superalloy) under specific CVD process conditions. The chemical composition was analysed in the cross-section of specimens at 7 points starting from the edge into the material core (Figure 2b, Table 2). The highest content of aluminium $(\sim 23 \%)$ was found near the surface. The mass volume of aluminium did not change significantly in the cross-section of specimen $(x 1-x 3)$ as its content of $\sim 20 \%$ was also observed in lower layers (x4-x6). Additionally, the slight increase of chromium and cobalt can be observed in the central part of layer. The surface of the layer consists of large, NiAl intermetallic crystallites that formed an intermetallic superstructure (secondary solid solution $\beta$ with B2 ordered structure) [34]. One can indicate that CVD conditions applied allowed to obtain a good coating coherence to the substrate since no defects were observed between coated material and coating itself. Some discontinuities found between sub-layers were caused by the extensive grinding during preparation of the specimens for the microstructural characterization.
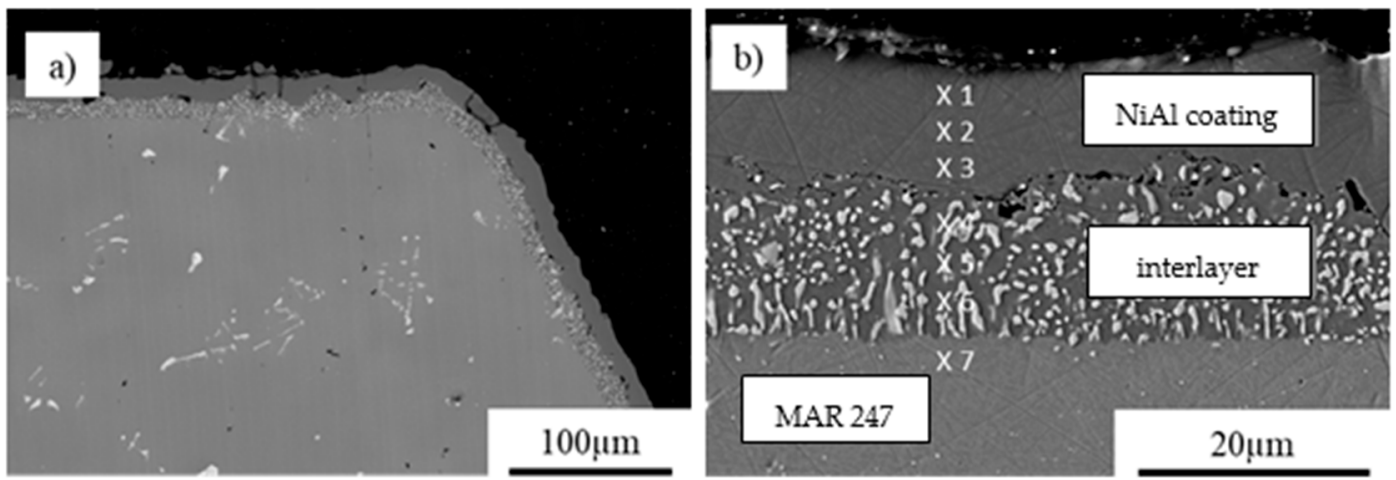

Figure 2. Microstructure of intermetallic coating produced by CVD method on MAR 247 nickel based superalloy at $1040{ }^{\circ} \mathrm{C}$ : (a) general view of the coating; (b) view of coating with points of EDS analysis marked.

Table 2. Chemical composition (wt.\%) of coating surface obtained after deposition at $1040{ }^{\circ} \mathrm{C}$.

\begin{tabular}{ccccccc}
\hline Point & Al & Si & Ti & Cr & Co & Ni \\
\hline x1 & 22.99 & - & - & 2.91 & 8.37 & 65.33 \\
x2 & 21.92 & - & 0.40 & 4.30 & 9.13 & 64.25 \\
x3 & 20.63 & - & 0.69 & 5.35 & 9.69 & 63.65 \\
x4 & 19.59 & 0.45 & 0.86 & 5.78 & 10.05 & 63.28 \\
x5 & 18.49 & 0.66 & 1.02 & 6.34 & 10.50 & 63.00 \\
x6 & 18.25 & 0.69 & 1.04 & 6.68 & 9.87 & 63.48 \\
x7 & 7.24 & 1.98 & 0.94 & 6.33 & 9.11 & 66.13 \\
\hline
\end{tabular}

The hardness distribution was measured from the edge of the coating in its crosssection, (Figure 3). The microhardness of the near-surface NiAl coating zone was equal to $664 \pm 25$ HV0.05 and decreases towards the surface layer of MAR 247 nickel based superalloy to $450 \pm 20 \mathrm{HV} 0.05$. The hardness of transition area was approx. $550 \pm 40 \mathrm{HV} 0.05$. 
The fluctuations founded in this area were related to the nonhomogeneous structure consisted of the hard $\mathrm{NiAl}$ phase and softer $\mathrm{Ni}_{3} \mathrm{Al}$ phase. It was observed that hardness varied with the content of different alloying elements.

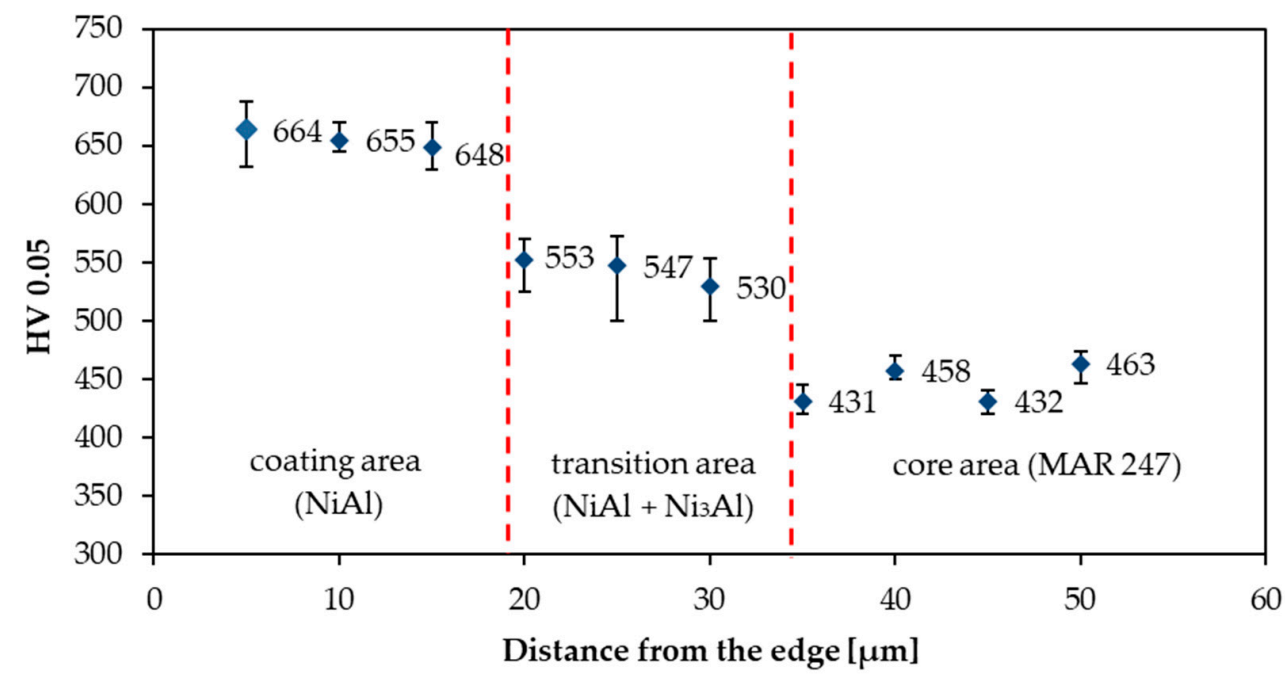

Figure 3. Hardness distribution in the cross-section of coating obtained.

\subsection{Effect of Coating on Tensile, Fatigue and Creep Performance of MAR 247 Nickel Based Superalloy}

Thermal barrier coatings are playing an increasingly significant role in the advanced gas turbine engines used in aero applications. Current research is focused on development of a new materials for both coatings and turbine blades. The basic properties of these materials are mainly characterized within their microscale using scanning electron microscopy or $\mathrm{X}$-ray diffraction. The mechanical properties are usually evaluated by nanoindentation or microhardness tests. It should be emphasized, however, that the turbine blades are mainly subjected to mechanical loadings at elevated temperature [37]. Unfortunately, not sufficient number of publications was found in this area. Thus, the main aim of work presented here was to perform a wide range of mechanical tests including standard, monotonic tension, fatigue and creep tests to characterized the mechanical response of coated MAR 247 nickel based superalloy at room and elevated temperature.

The uniaxial tensile tests were carried out at room temperature and $1000{ }^{\circ} \mathrm{C}$ on coated and uncoated MAR 247 nickel based superalloy. The slight difference of mechanical response was observed for the material tested at room temperature. It has been found, however, that aluminide layer could enhance the high temperature performance of nickel alloy. A considerable improvements of mechanical properties were achieved during testing at $1000{ }^{\circ} \mathrm{C}$ (Table 3). The results obtained were similar to those presented in [6] for MAR 247 nickel based superalloy. Moreover, a significant improvement of the yield strength at elevated temperature by approximately of $20 \%$ in comparison to Rene 80 [7] and IN738 [8] were found after testing. It should be mentioned, that the coated MAR 247 nickel based superalloy exhibited a comparable mechanical response of such materials as CMSX or Rene 500 [38]. One can indicate, that the aluminide thermal barrier coating used in the conventional MAR 247 nickel based superalloy enhanced the tensile properties of nickel superalloy at high temperature. Moreover, these results suggest, that material tested possessed the equivalent properties to those of the high-strength single crystal superalloys. 
Table 3. Selected mechanical properties for coated and uncoated MAR 247 nickel based superalloy after uniaxial tensile test performed at room temperature and $1000{ }^{\circ} \mathrm{C}$.

\begin{tabular}{|c|c|c|c|c|c|c|c|c|}
\hline \multirow{2}{*}{ Material } & \multicolumn{4}{|c|}{ Room Temperature } & \multicolumn{4}{|c|}{$1000^{\circ} \mathrm{C}$} \\
\hline & $R_{\mathrm{m}}(\mathrm{MPa})$ & $R_{\mathrm{e}}(\mathrm{MPa})$ & $E(\mathrm{GPa})$ & $A(\%)$ & $R_{\mathrm{m}}(\mathrm{MPa})$ & $R_{\mathrm{e}}(\mathrm{MPa})$ & $E(\mathrm{GPa})$ & $A(\%)$ \\
\hline Uncoated MAR 247 nickel based superalloy & 980 & 800 & 185 & 6 & 380 & 330 & 85 & 5 \\
\hline Coated MAR 247 nickel based superalloy & 1100 & 830 & 197 & 6 & 460 & 415 & 98 & 8 \\
\hline
\end{tabular}

$R_{\mathrm{m}}$ is tensile strength, $R_{\mathrm{e}}$ is yield point, $E$ is Young's modulus, $A$ is elongation.

The effect of coating on mechanical properties of MAR247 nickel based superalloy was investigated in either standard or high temperature fatigue tests. The results shown that coating slightly decrease the elongation of the MAR 247 nickel based superalloy specimens at room temperature while the stress response remained at the similar level (Figure 4a). A significant improvement of mechanical properties was observed during high temperature fatigue testing where the strength of coated specimen increased almost twice in comparison to the as-received material (Figure 4b). Sulak et al. [37] reported that cyclic deformation of nickel-based superalloys can be particularly determined by the interaction analysis between dislocations and $\gamma$ strengthening phase, where precipitates played a role as an effective barriers against the dislocations movement. Moreover, high temperature performance resulted on phase changes, precipitate coarsening and oxidation [38,39]. All these features led to essential softening of the nickel superalloys.

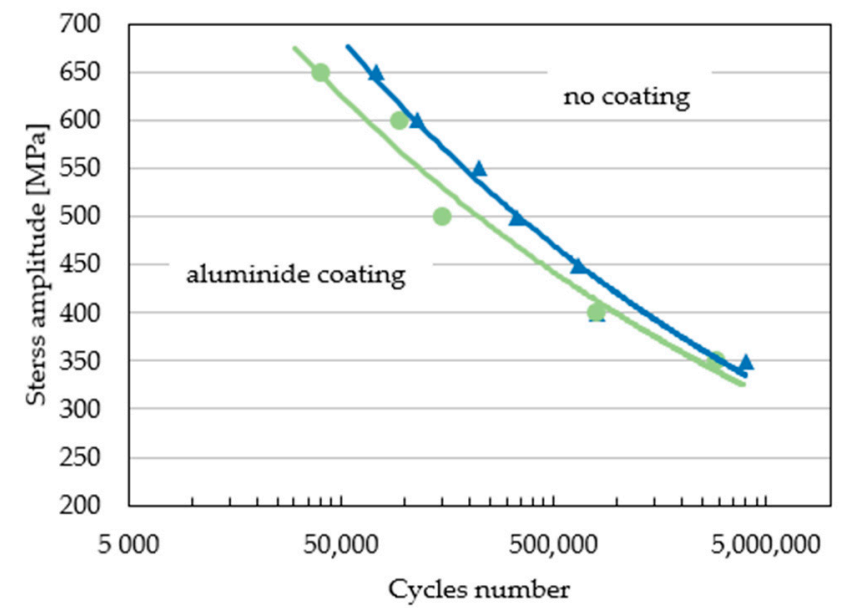

(a)

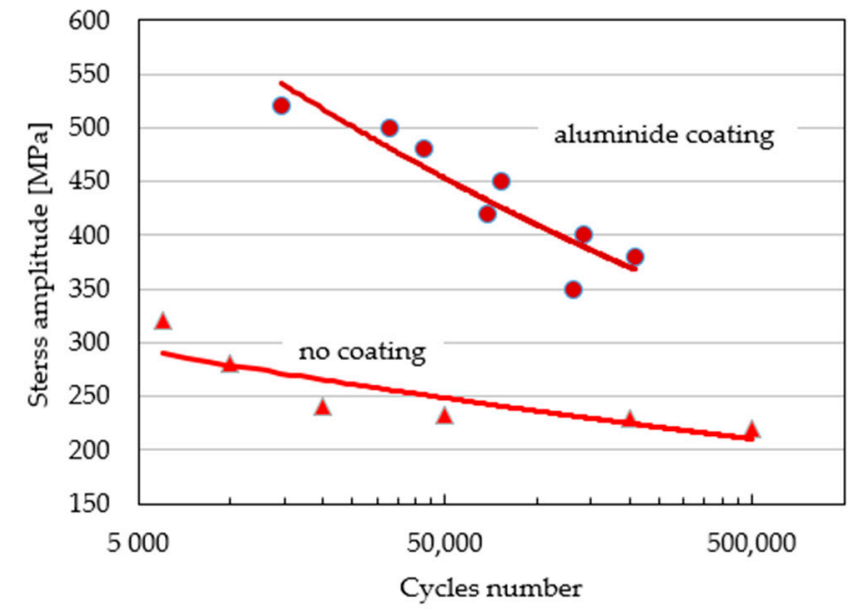

(b)

Figure 4. S-N curves of coated and uncoated MAR247 nickel based superalloy determined at: (a) room temperature; (b) $900{ }^{\circ} \mathrm{C}$. 
It is found that aluminides coating of $20 \mu \mathrm{m}$ thickness obtained by CVD process slightly reduced the room temperature performance (Figure $4 \mathrm{a}$ ). Completely opposite effect was achieved for the same material tested at $900{ }^{\circ} \mathrm{C}$. In this case almost $100 \%$ variation of stress amplitude can be easily observed in Figure $4 \mathrm{~b}$. Similar strength improvement may be observed in comparison to the conventional, uncoated nickel alloys such as IN 792-5A and IN 713LC during fatigue testing at $900{ }^{\circ} \mathrm{C}$ [40]. One can conclude that an application of the aluminide layer can improve significantly the nickel superalloys behavior, and additionally, it can prevent the raw material against such processes as oxidation, hot corrosion, or wear, thus providing a longer life-time [41]. It should be emphasized, that coating obtained in the authors previous study [34] was characterized by the very good adherence, wear and thermal resistance confirmed by experimental studies. Its application significantly improved the hardness and wear in comparison to the as-received MAR 247 nickel based superalloy substrate. The excellent durability and tightness of the protective scale resulted in no scale spallation. It could be concluded, that such aluminide layer considerably enhance the high temperature fatigue performance of MAR 247 nickel based superalloy, and thus, could be successfully applied for nickel alloys. Similar improvement of functional properties of Inconel 713 LC Ni-based superalloy protected with aluminide layer deposited on it during the CVD process was reported in the available papers e.g., [28].

After mechanical testing, the microstructural observations were carried out. They enabled identifications of defects induced due to the loading history defined. Looking at the fracture surfaces, one can indicate a greater or lesser cluster of cracks (Figure 5a,b). Their formation was initiated in the last stage of fatigue, when the strain concentration zone was already formed. This confirms the assumption that cracks in the aluminide layer are preceded by cracks in the entire specimen volume. Such behavior indicates a lower fatigue strength of the layer in comparison to the nickel alloy core.
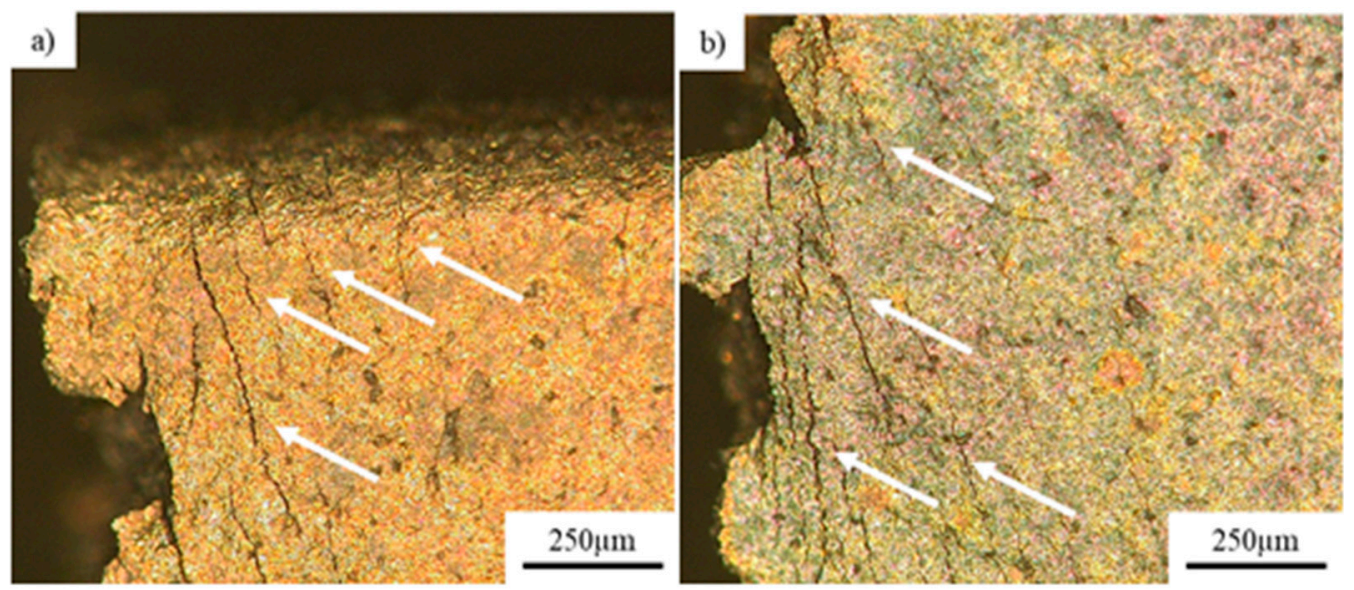

Figure 5. Microscopic views of the side surfaces of specimens after fatigue tests with visible cracking of the layer in the direction perpendicular to that of deformation: (a) edge of the specimen; (b) center of the specimen.

The scanning microscope observations of fracture areas of specimens subjected to cyclic loading at room temperature showed that the crack propagation in the layer was not transferred into the nickel matrix. The view of fracture area confirm the permanence of the interfacial adhesion as no cracks between the layer and nickel substrate were observed (Figure 6a). Such behavior can be a sign of good efficiency of CVD process applied. It should be emphasized additionally, that a satisfied layer coherence was attained (Figure 6b). Despite the multiple cracks, the layer remained adhered to the nickel based substrate. Numerous cracks in the aluminide layer were observed near the decohered area (Figure 6c). However, cracks in the layer itself do not limit the possibility of cyclic load carrying. Despite the multiple cracks found on the edge of the sample (Figure 6c), it broke within the gauge. Such behavior may suggest, that the aluminide layer is not responsible for 
crack initiation. Moreover, it protects the MAR 247 nickel based superalloy against the high temperature exposure, and as a consequence, successfully extends its service life. One can indicate that good coherence between layer and substrate could further improve the mechanical response of matrix material [42].
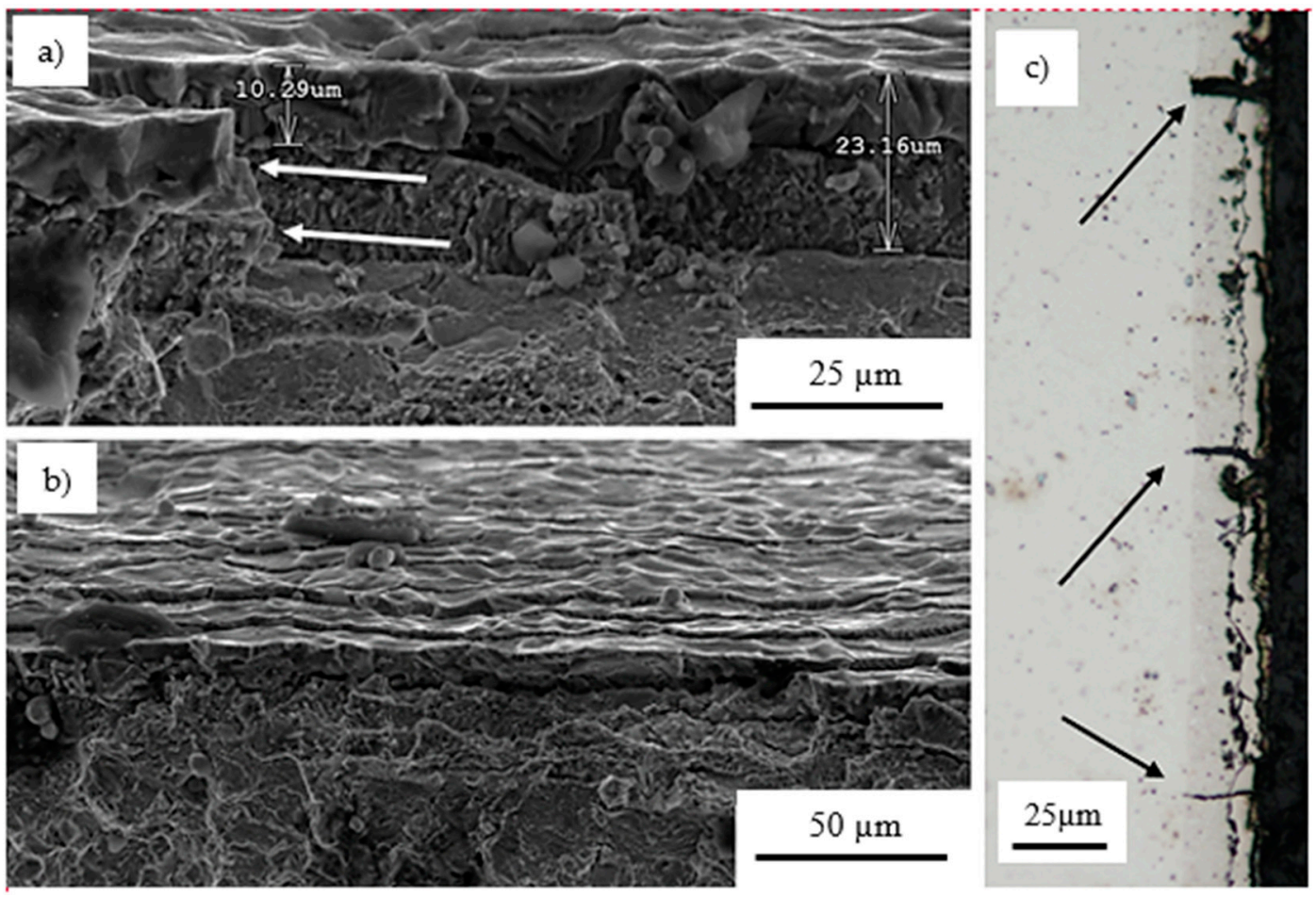

Figure 6. Fracture surface observations: (a) propagation of crack through coating without visible cracks in core material; (b) morphology of coating after fatigue at room temperature; (c) multiple layer cracks.

In the next step of experimental program, the coated and uncoated MAR247 nickel based superalloy was subsequently subjected to creep at $600{ }^{\circ} \mathrm{C}$ in the air atmosphere (Figure 7a). It is shown that aluminized layer improved the creep performance of the alloy investigated. The strength enhancement of more than $50 \mathrm{MPa}$ was observed when the high temperature exposure time extended $500 \mathrm{~h}$. The stress response of coated MAR 247 nickel based superalloy tend to decrease steadily with temperature increase while for uncoated material it decreases significantly. It was anticipated that the long time exposure $(>1000 \mathrm{~h})$ at high temperature and constant load could even increase the difference in stress response for coated and uncoated material (Figure 7b). Similar work was reported by Yuan et al. [43] where the IN792 in the as-received state and with NiAl protective coating was subjected to creep at temperature of $850{ }^{\circ} \mathrm{C}$ and $950{ }^{\circ} \mathrm{C}$. It was concluded, that the crack initiation and propagation mechanisms were temperature dependent. For the polycrystalline superalloy tested at both temperatures, the grain-boundary separation was the main failure mode. In the $\mathrm{NiAl}$ coated material, the formation of $\gamma^{\prime}$ along grain boundary in the layer zone at $850^{\circ} \mathrm{C}$ could induce active through-coating cracks, which may further penetrate into the substrate along the nearest grain boundary beneath the coating. However, a formation of $\gamma^{\prime}$ in the layer was restricted to $950{ }^{\circ} \mathrm{C}$.

Thermal stability of the coated MAR 247 nickel based superalloy was evaluated through the in-situ Young's modulus measurements in temperature range from 22 to $900{ }^{\circ} \mathrm{C}$ during annealing and cooling at a rate of $3{ }^{\circ} \mathrm{C} / \mathrm{min}$ to $900{ }^{\circ} \mathrm{C}$. RFDA method allowed to monitor an evolution of the Young's modulus with the heating temperature as well as during cooling to room temperature (Figure 8). It was found that such nondestructive method could precisely determine the Young's modulus value in a wide range of temperature. The results were comparable to those obtained from uniaxial tensile tests. 
It was concluded that RFDA method could be successfully applied for the non-destructive Young's modulus measurements of coated MAR 247 nickel based superalloy.

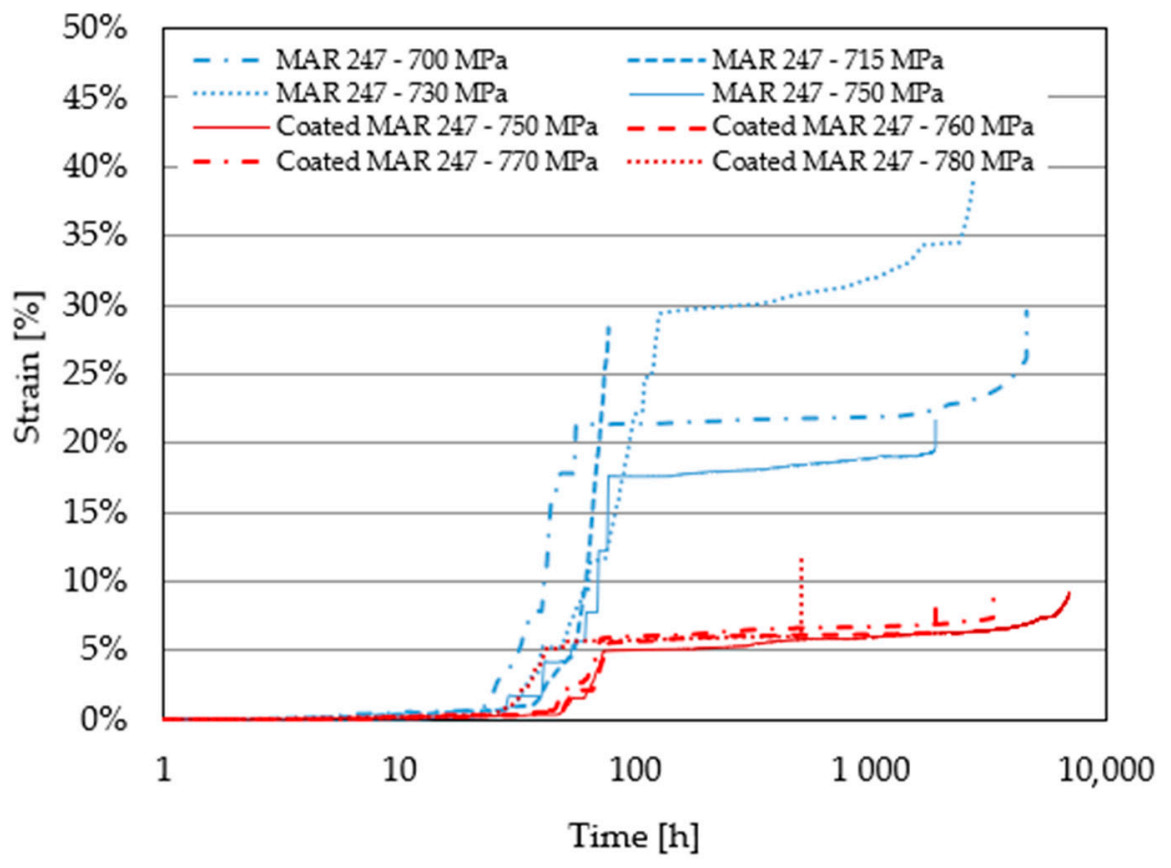

(a)

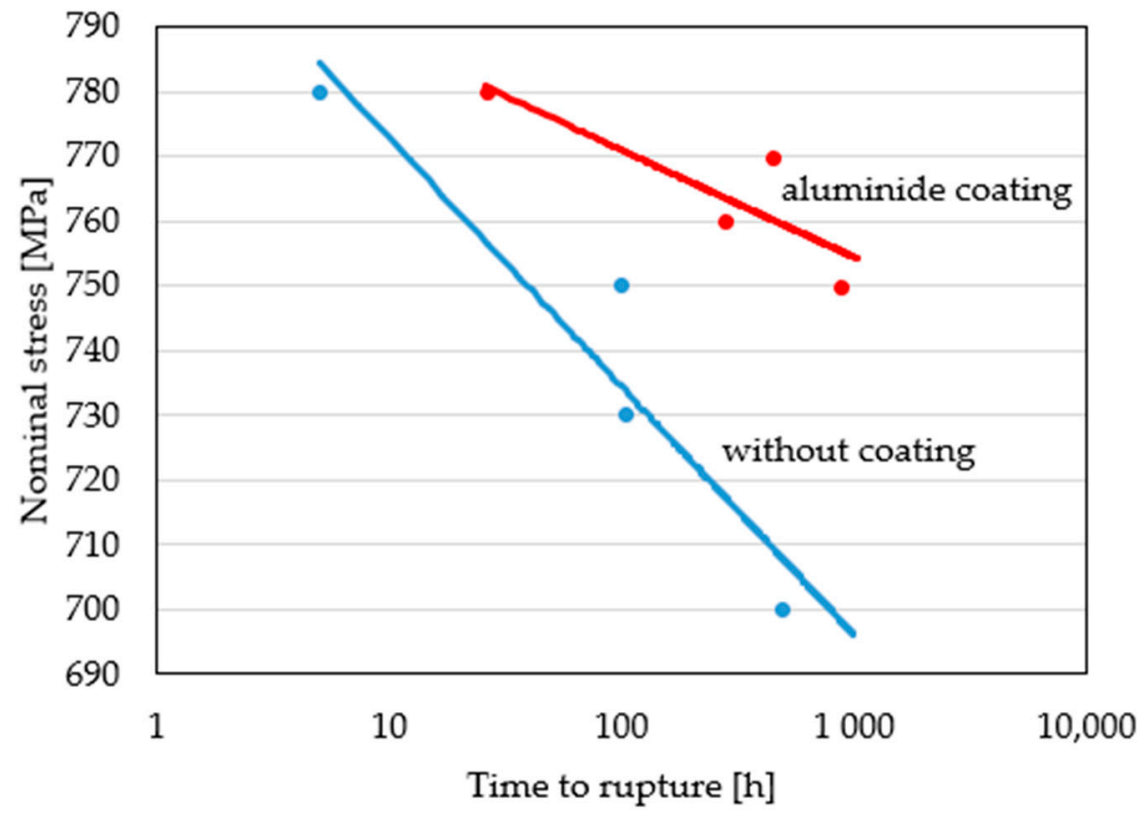

(b)

Figure 7. Creep characteristics of coated and uncoated MAR 247 nickel based superalloy (a); effect of stress level on time to rupture of coated and uncoated MAR247 nickel based superalloy subjected to creep at $600{ }^{\circ} \mathrm{C}(\mathbf{b})$. 


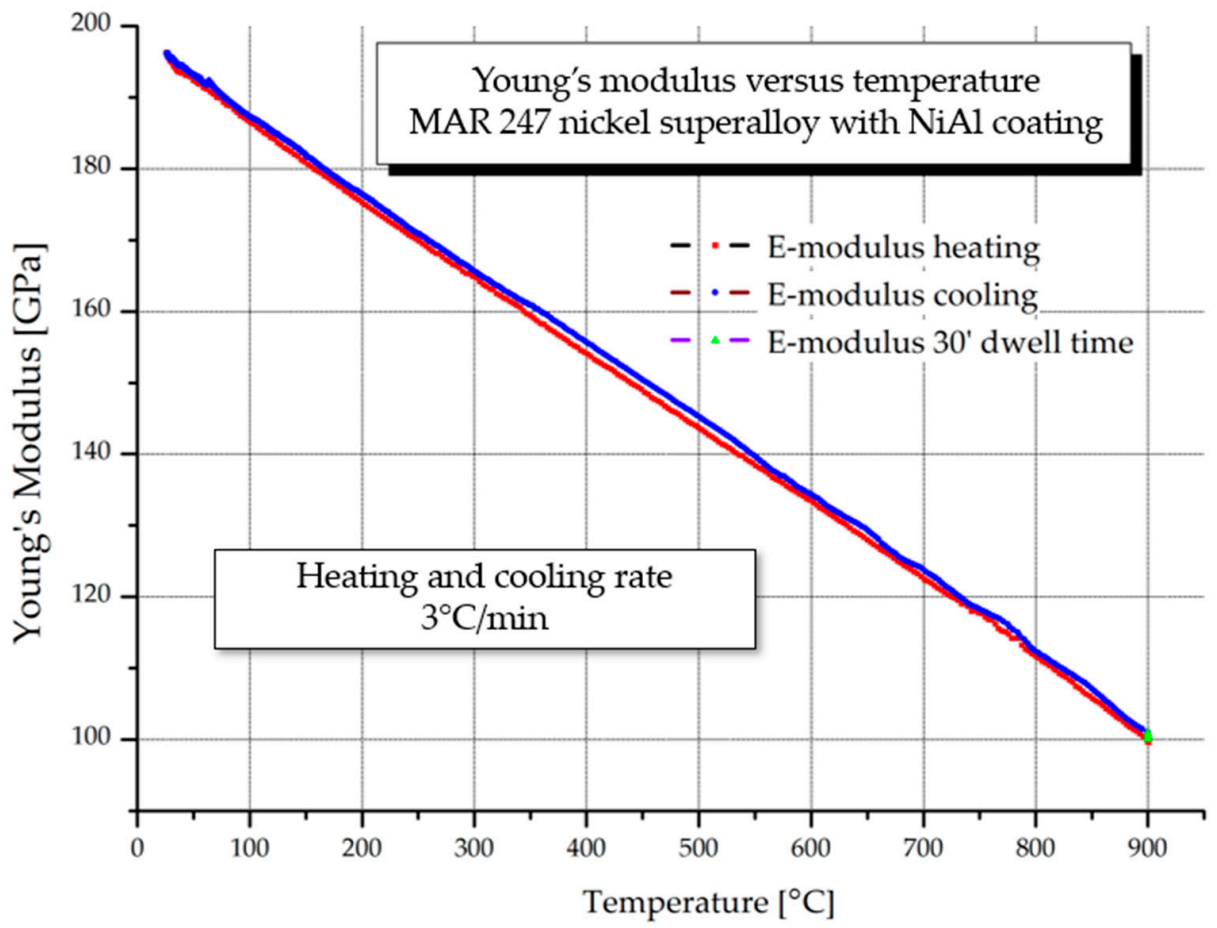

Figure 8. Evolution of the Young's modulus of coated MAR 247 nickel based superalloy at the temperature of $22-900{ }^{\circ} \mathrm{C}$, during annealing and cooling at a rate of $3{ }^{\circ} \mathrm{C} / \min$ to $900{ }^{\circ} \mathrm{C}$.

\section{Conclusions}

Optimization of CVD parameters for MAR247 nickel based superalloy with respect to the thermal process applied in the protective hydrogen atmosphere enabled to get an effective, non-defected thermal barrier coating with the uniform thickness. The coating was characterized by a very good adherence and thermal resistance. CVD technology with parameters carefully determined could be successfully used to enhance the mechanical properties of MAR 247 nickel based superalloy. An essential improvement of the strength response during cyclic loading (about $200 \mathrm{MPa}$ ) of the coated nickel superalloy in comparison to that of the as-received material achieved was identified at $900^{\circ} \mathrm{C}$. Such feature was not observed at room temperature, where the stress response was almost the same. One can conclude, that the aluminized layer may improve the creep performance of the nickel superalloy significantly. It is evidenced that application of such layer may effectively protect the raw material against such processes as oxidation, hot corrosion or wear, and thus, extend its service life.

Author Contributions: Conceptualization, M.K. and D.K.; methodology, D.K., M.K, X.Y., W.R. and C.S.; formal analysis, M.K., C.S. and Z.L.K.; writing—original draft preparation M.K.; writing—review and editing, C.S. and Z.L.K. All authors have read and agreed to the published version of the manuscript.

Funding: The authors gratefully acknowledge the funding by The National Centre for Research and Development, Poland, under Program for Applied Research, grant no. 178781.

Institutional Review Board Statement: Not applicable.

Informed Consent Statement: Not applicable.

Data Availability Statement: Data available in a publicly accessible repository.

Acknowledgments: The authors are grateful to Mirosław Wyszkowski and Andrzej Chojnacki from the Institute of Fundamental Technological Research of the Polish Academy of Sciences for their great support of the experimental work.

Conflicts of Interest: The authors declare no conflict of interest. 


\section{References}

1. Agarwal, D.C.; Brill, U. High-temperature-strength nickel alloy. Adv. Mater. Process. 2000, 158, 31-34.

2. Wanhill, R.J.H. Fatigue of air supply manifold support rod in military jet engines. JFAP 2004, 4, 53-61. [CrossRef]

3. Goward, G.W. Progress in coatings for gas turbine airfoils. Surf. Coat. Technol. 1998, 1, 73-79. [CrossRef]

4. $\quad$ Reed, C.R. The Superalloys-Fundamentals and Applications; C.U.P.: Cambridge, UK, 2006; ISBN 0511-24546-7.

5. Barbosa, C.; Nascimento, J.L.; Caminha, I.M.V.; Abud, I.C. Microstructural aspects of the failure analysis of nickel base superalloys components. Eng. Fail. Anal. 2005, 12, 348-361. [CrossRef]

6. Kaufman, M. Properties of cast Mar-M-247 for turbine blisk applications. Superalloys 1984, 43-52. [CrossRef]

7. Fritz, L.J.; Koster, W.P. Tensile and Creep Rupture Properties of (1) Uncoated and (2) Coated Engineering Alloys at Elevated Temperatures; NASA Technical Report; NAS CR-135138; NASA: Washington, DC, USA, 1977.

8. NCO. Alloy IN-738 Technical Data; The International Nickel Company, Inc.: New York, NY, USA; Available online: https://www. nickelinstitute.org/media/1709/in_738alloy_preliminarydata_497_.pdf (accessed on 1 December 2020).

9. Wee, S.; Do, J.; Kim, K.; Lee, C.; Seok, C.; Choi, B.-G.; Choi, Y.; Kim, W. Review on mechanical thermal properties of superalloys and thermal barrier coating used in gas turbines. Appl. Sci. 2020, 10, 5476. [CrossRef]

10. Kawahara, Y. Application of high temperature corrosion-resistant materials and coatings under severe corrosive environment in waste-to-energy boilers. J. Therm. Spray Tech. 2007, 16, 202-213. [CrossRef]

11. Sadeghi, E.; Markocsan, N.; Joshi, S. Advances in corrosion-resistant thermal spray coatings for renewable energy power plants: Part II-Effect of environment and outlook. J. Therm. Spray Tech. 2019, 28, 1789-1850. [CrossRef]

12. Jozwik, P.; Polkowski, W.; Bojar, Z. Applications of Ni3Al based intermetallic alloys—Current stage and potential perceptivities. Materials 2015, 8, 2537-2568. [CrossRef]

13. Cinca, N.; Lima, C.R.C.; Guilemany, J.M. An overview of intermetallics research and application: Status of thermal spray coatings. JMRTAL 2013, 2, 75-86. [CrossRef]

14. Bochenek, K.; Basista, M. Advances in processing of NiAl intermetallic alloys and composites for high temperature aerospace applications. Prog. Aerosp. Sci. 2015, 79, 136-146. [CrossRef]

15. Curry, N.; Markocsan, N.; Li, X.H.; Tricoire, A.; Dorfman, M. Next generation thermal barrier coatings for the gas turbine industry. J. Therm. Spray Tech. 2011, 20, 108-115. [CrossRef]

16. Zagula-Yavorska, M.; Sieniawski, J.; Filip, R.; Drajewicz, M. The effect of the aluminide coating on the thermal properties and oxidation resistance of Inconel 625 Ni-base superalloy. Solid State Phenom. 2015, 227, 313-316. [CrossRef]

17. Stekovic, S. Low cycle fatigue and fracture of a coated superalloy CMSX-4. In Fracture of Nano and Engineering Materials and Structures; Gdoutos, E.E., Ed.; Springer: Dordrecht, The Netherland, 2006. [CrossRef]

18. Okazaki, M. High-temperature strength of Ni-base superalloy coatings. Sci. Technol. Adv. Mat. 2001, 2, 357-366. [CrossRef]

19. Rodriguez, P.; Mannan, S.L. High temperature low cycle fatigue. Sadhana 1995, 20, 123-164. [CrossRef]

20. Castillo, R.; Willett, K.P. The effect of protective coatings on the high temperature properties of a gamma prime-strengthened Ni-base superalloy. Metall. Mater. Trans. A 1984, 15, 229-236. [CrossRef]

21. Veys, J.M.; Mevrel, R. Influence of protective coatings on the mechanical properties of CMSX-2 and Cotac 784. Mater. Sci. Eng. A 1987, 88, 253-260. [CrossRef]

22. Kalivodova, J.; Baxter, D.; Schutze, M.; Rohr, V. Corrosion behaviour of boiler steels, coatings and welds in flue gas environments. Mater. Corros. 2008, 59, 367-373. [CrossRef]

23. Kochmańska, A.; Garbiak, M. High-temperature diffusion barrier for Ni-Cr Cast Steel. Defect Diffus. Forum. 2011, 595-600. [CrossRef]

24. Zhan, Z.; He, Y.; Li, L.; Liu, H.; Dai, Y. Low-temperature formation and oxidation resistance of ultrafine aluminide coatings on Ni-base superalloy. Surf. Coat. Technol. 2009, 203, 2337-2342. [CrossRef]

25. Xu, Z.H.; Dai, J.W.; Niu, J.; He, L.M.; Mu, R.D.; Wang, Z.K. Isothermal oxidation and hot corrosion behaviors of diffusion aluminide coatings deposited by chemical vapor deposition. J. Alloys Compd. 2015, 637, 343-349. [CrossRef]

26. Wang, K.L.; Chen, F.S.; Leu, G.S. The aluminizing and Al-Si codeposition on AISI HP alloy and the evaluation of their carburizing resistance. Mater. Sci. Eng. A 2003, 357, 27-38. [CrossRef]

27. Wang, Y.; Chen, W. Microstructures, properties and high-temperature car-burization resistances of HVOF thermal sprayed NiAl intermetallic-based alloy coatings. Surf. Coat. Technol. 2004, 183, 18-28. [CrossRef]

28. Yavorska, M.; Sieniawski, J.; Zielińska, M. Functional properties of aluminide layer deposited on inconel 713 lc ni-based superalloy in the CVD process. Arch. Metall. Mater. 2011, 56, 187-192. [CrossRef]

29. Bojar, Z.; Jóźwik, P.; Bystrzycki, J. Tensile properties and fracture behavior of nanocrystalline Ni3Al intermetallic foil. Scr. Mat. 2006, 55, 399-402. [CrossRef]

30. Polkowski, W.; Józwik, P.; Karczewski, K.; Bojar, Z. Evolution of crystallographic texture and strain in a fine-grained Ni3Al (Zr, B) intermetallic alloy during cold rolling. Arch. Civ. Mech. Eng. 2014, 14, 550-560. [CrossRef]

31. Adamiak, S.; Bochnowski, W.; Dziedzic, A.; Filip, R.; Szeregij, E. Structure and properties of the aluminide coatings on the Inconel 625 superalloy. High. Temp. Mat. Pr. Isr. 2016, 35, 103-112. [CrossRef]

32. Ning, B.; Stevenson, M.E.; Weaver, M.L.; Bradt, R.C. Apparent indentation size effect in a CVD aluminide coated Ni-base superalloy. Surf. Coat. Technol. 2003, 163, 112-117. [CrossRef]

33. Zagula-Yavorska, M.; Kocurek, P.; Pytel, M. Oxidation resistance of turbine blades made of ŻS6K superalloy after aluminizing by Low-Activity CVD and VPA Methods. J. Mater. Eng. Perform. 2016, 25, 1964-1973. [CrossRef] 
34. Kukla, D.; Kopec, M.; Kowalewski, Z.L.; Politis, D.J.; Jozwiak, S.; Senderowski, C. Thermal barrier stability and wear behavior of CVD deposited aluminide coatings for MAR 247 nickel superalloy. Materials 2020, 12, 3863. [CrossRef] [PubMed]

35. Maxwell, A.S.; Owen-Jones, S.; Jennett, N.M. Measurement of Young's modulus and Poisson's ratio of thin coatings using impact excitation and depth-sensing indentation. Rev. Sci. Instrum. 2004, 75, 970-975. [CrossRef]

36. ASTM E1876-99. Standard Test Method for Dynamic Young's Modulus, Shear Modulus, and Poisson's Ratio by Impulse Excitation of Vibration; ASTM International: West Conshohocken, PA, USA, 2001.

37. Sulak, I.; Obrtlik, K.; Celko, L. High-temperature low-cycle fatigue behaviour of HIP treated and untreated superalloy MAR-M247. Kovove Mater. 2016, 54, 471-481. [CrossRef]

38. Corrigan, J.; Launsbach, M.G.; Mihalisin, J.R. Nickel Base Superalloy and Single Crystal Castings. U.S. Patent 8,241,560, 14 August 2012.

39. Antolovich, S.D. Microstructural aspects of fatigue in Ni-base superalloys. Phil. Trans. R. Soc. A 2015, 373, 20140128. [CrossRef] [PubMed]

40. Šmíd, M.; Kunz, L.; Hutař, P.; Hrbáček, K. High cycle fatigue of nickel-based superalloy MAR-M 247 at high temperatures. Proc. Eng. 2014, 74, 329-332. [CrossRef]

41. Rahmani, K.; Nategh, S. Mechanical properties of uncoated and aluminide-coated René 80. Metall. Mater. Trans. A Phys. Metall. Mater. Sci. 2010, 41, 125-137. [CrossRef]

42. Samal, S.; Tyc, O.; Heller, L.; Šittner, P.; Malik, M.; Poddar, P.; Catauro, M.; Blanco, I. Study of interfacial adhesion between nickel-titanium shape memory alloy and a polymer matrix by laser surface pattern. Appl. Sci. 2020, 10, 2172. [CrossRef]

43. Yuan, K.; Peng, R.; Li, X.-H.; Johansson, L.; Johansson, S.; Wang, Y. Creep fracture mechanism of polycrystalline Ni-based superalloy with diffusion coatings. In Proceedings of the 13th International Conference on Fracture ICF13, Beijing, China, 16-21 June 2013. Available online: http:/ / urn.kb.se/ resolve?urn=urn:nbn:se:liu:diva-8949 (accessed on 1 December 2020). 